\title{
Recent advances in understanding antiphospholipid
}

\section{syndrome [version 1; peer review: 2 approved]}

\author{
Maria Laura Bertolaccini(D1, Giovanni Sanna² \\ ${ }^{1}$ Academic Department of Vascular Surgery, Cardiovascular Division, King's College London, London, UK \\ 2Louise Coote Lupus Unit, Guy's and St Thomas' NHS Foundation Trust, London, UK
}

V1 First published: 22 Dec 2016, 5(F1000 Faculty Rev):2908

https://doi.org/10.12688/f1000research.9717.1

Latest published: 22 Dec 2016, 5(F1000 Faculty Rev):2908

https://doi.org/10.12688/f1000research.9717.1

\section{Abstract}

Antiphospholipid syndrome (APS), also known as Hughes Syndrome, is a systemic autoimmune disease characterized by thrombosis and/or pregnancy morbidity in the presence of persistently positive antiphospholipid antibodies. A patient with APS must meet at least one of two clinical criteria (vascular thrombosis or complications of pregnancy) and at least one of two laboratory criteria including the persistent presence of lupus anticoagulant (LA), anticardiolipin antibodies (aCL), and/or anti-b2 glycoprotein I (anti-b2GPI) antibodies of IgG or IgM isotype at medium to high titres in patient's plasma. However, several other autoantibodies targeting other coagulation cascade proteins (i.e. prothrombin) or their complex with phospholipids (i.e. phosphatidylserine/prothrombin complex), or to some domains of $\beta 2 \mathrm{GPI}$, have been proposed to be also relevant to APS. In fact, the value of testing for new aPL specificities in the identification of APS in thrombosis and/or pregnancy morbidity patients is currently being investigated.

Keywords

antiphospholipid syndrome, APS, Hughes Syndrome,

\section{Open Peer Review}

Approval Status

1 2

version 1

22 Dec 2016

Faculty Reviews are review articles written by the prestigious Members of Faculty Opinions. The articles are commissioned and peer reviewed before publication to ensure that the final, published version is comprehensive and accessible. The reviewers who approved the final version are listed with their names and affiliations.

1. Imad Uthman, Division of Rheumatology, American University of Beirut, Beirut, Lebanon

2. Michael D Lockshin, Hospital for Special Surgery, Weill Cornell Medical College, New York, USA

Any comments on the article can be found at the end of the article. 
Corresponding author: Maria Laura Bertolaccini (laura.bertolaccini@kcl.ac.uk)

Competing interests: The authors declare that they have no completing interests.

Grant information: The author(s) declared that no grants were involved in supporting this work.

Copyright: @ 2016 Bertolaccini ML and Sanna G. This is an open access article distributed under the terms of the Creative Commons Attribution License, which permits unrestricted use, distribution, and reproduction in any medium, provided the original work is properly cited.

How to cite this article: Bertolaccini ML and Sanna G. Recent advances in understanding antiphospholipid syndrome [version 1; peer review: 2 approved] F1000Research 2016, 5(F1000 Faculty Rev):2908 https://doi.org/10.12688/f1000research.9717.1

First published: 22 Dec 2016, 5(F1000 Faculty Rev):2908 https://doi.org/10.12688/f1000research.9717.1 


\section{Introduction}

Antiphospholipid syndrome (APS), also known as Hughes Syndrome, is a systemic autoimmune disease characterized by thrombosis and/or pregnancy morbidity in the presence of persistently positive antiphospholipid antibodies ${ }^{1}$. When APS was first described, it was in the presence of systemic lupus erythematosus $(\mathrm{SLE})^{2}$; however APS is now accepted to be a primary autoimmune syndrome with other accompanying characteristics, such as thrombocytopenia, seizure disorder, cognitive dysfunction, livedo reticularis, and renal vasculopathy, being frequent in the absence of the main clinical manifestations of thrombosis and pregnancy complications ${ }^{3}$.

In 1999 definitive classification criteria for APS were published in an international consensus statement ${ }^{4}$ and subsequently revised in $2006^{1}$. A patient with APS must meet at least one of two clinical criteria (vascular thrombosis or complications of pregnancy) and at least one of two laboratory criteria including the persistent presence of lupus anticoagulant (LA), anticardiolipin antibodies (aCL) and/ or anti- $\beta 2$ glycoprotein I (anti- $\beta 2 \mathrm{GPI}$ ) antibodies of $\operatorname{IgG}$ or IgM isotype at medium to high titres in patient's plasma.

While it is widely accepted that the LA is the most important predictor for thrombosis ${ }^{5-7}$, several other autoantibodies targeting other coagulation cascade proteins (i.e. prothrombin) or their complex with phospholipid (i.e. phosphatidylserine/prothrombin complex), or to some domains of $\beta 2 \mathrm{GPI}$, have been proposed to be relevant to APS ${ }^{8}$. In fact, the value of testing for new aPL specificities in the identification of APS in thrombosis and/or pregnancy morbidity patients is currently being evaluated, which will be especially useful for those with recurrent negative results in present tests?

\section{New aPL specificities}

Antibodies directed to the domain I of the $\beta 2 \mathrm{GPI}$

$\beta 2$ GPI was identified as a primary target of autoantibodies in patients with APS $^{10}$. $\beta 2$ GPI is a single-chain protein containing five repeating sequences or domains. Domain V is essential for binding to anionic phospholipid membranes, whereas domain I sticks out into the extracellular space where interactions with other proteins/antibodies can take place ${ }^{11}$. The development of recombinant domain specific 32 GPI molecules by Iverson et al. in $1998^{12}$ steered us towards a better understanding of the specific role of the autoantibodies to each of the five $\beta 2$ GPI domains. Several studies have detected antibodies recognizing various domains of $\beta 2 \mathrm{GPI}^{13}$. However, anti-domain I (anti-DI) antibodies were frequently found to be highly associated with clinical symptoms and therefore focused upon ${ }^{14,15}$.

In their 2005 study, de Laat et al. reported that patients testing positive for anti-DI had a higher thrombosis risk ${ }^{14}$. Antibodies recognizing epitope G40-R43 on the domain I of $\beta 2$ GPI caused LA and strongly correlated with thrombosis ${ }^{14}$. A larger, multicentre study in 2009 looked at a large cohort of anti- $\beta 2$ GPI positive patients, showing that those patients who were IgG anti-DI positive had a 3.5 fold increase in the risk of developing vascular thrombosis and a 2.4 fold increase in the risk of developing pregnancy morbidity when compared to those who tested negative for IgG anti-DI ${ }^{16}$. Using inhibition assays, Banzato et al. demonstrated that high-risk patients, those bearing triple aPL positivity for aCL, LA and anti- $\beta 2 \mathrm{GPI}$, are those with substantially greater titre of circulating anti-DI antibodies. Those with double and single positivity showed low titre or absence of anti-DI antibodies ${ }^{17}$. Conversely, when tested on 326 patients with SLE, of whom 164 had a history of thrombosis, Akhter et al. failed to find an association between anti-DI and these events ${ }^{18}$.

The domain profile of anti- $\beta 2$ GPI antibodies has also been explored in a large cohort of patients. While neither anti-DI nor anti-DIV/V antibodies were found to be associated with thrombotic events or obstetric morbidity, Andreoli et al. suggested that utilizing the ratio of anti-DI/anti-DIV/V could be useful as a biomarker for APS, identifying "pathogenic" from "nonpathogenic" anti- $\beta 2 \mathrm{GPI}^{15}$. A recent study in aCL and/or aß2GPI positive patients suggests that the added finding of anti-DI positivity makes it three to five times more likely to confirm APS. Positivity for $\operatorname{IgG}$ or $\operatorname{IgA}$ (but not $\operatorname{IgM}$ ) anti-DI increased the strength of association between aCL/aß2GPI and thrombotic manifestations in APS ${ }^{19}$.

Anti-DI antibodies have also been reported in pediatric populations. Wahezi et al. reported a prevalence of IgG anti-DI of $25.1 \%$ in children with SLE. However, only seven children had thrombosis, failing to ascertain a positive correlation ${ }^{20}$. In a study on 64 APS patients and 57 children born to mothers with systemic autoimmune diseases, Andreoli et al. showed a high prevalence of anti-DI in APS while there was a low anti-DI frequency reported in anti- $\beta 2$ GPI positive healthy children ${ }^{21}$.

A direct demonstration of the pathogenic effect of anti-DI antibodies has been recently shown using a human monoclonal IgG (MBB2), the infusion of which brought about fetal losses in pregnant mice and blood clots in rat mesenteric microcirculation following priming with lipopolysaccharide (LPS) ${ }^{22}$. Interestingly, a variant of this antibody, lacking the $\mathrm{CH} 2$ domain (MBB2D $\Delta \mathrm{CH} 2$ ), was effective in preventing blood clot formation and fetal loss induced by $\mathrm{aPL}^{22}$. A recombinant human domain I has also been shown to inhibit the ability of polyclonal human IgG from a patient with APS to cause thrombosis or to enhance tissue factor activity in an animal model ${ }^{23}$. Using polyclonal IgG from patients with APS, anti-domain I-rich IgG significantly enhanced prothrombotic ability in vivo compared with anti-domain I-poor or NHS-IgG, suggesting that the ability of human APS-derived IgG to cause thrombosis in mice is concentrated in the anti-domain I-rich fraction ${ }^{24}$.

A novel approach for developing therapy for APS has shown that tolerogenic dendritic cells specific for domain-I of the $\beta 2 \mathrm{GPI}$ molecule may have potential in attenuating experimental APS in a murine model, via acceleration of the differentiation of $\mathrm{CD}^{+} \mathrm{T}$ cells to Treg cells, decreased proinflammatory cytokine production, and increased anti-inflammatory cytokine expression (IL-10 and TGF $\beta)^{25}$.

Antibodies to prothrombin

Prothrombin (factor II) is an important antigenic target for aPL in APS. Prothrombin is a vitamin K-dependent single-chain glycoprotein of 579 amino acid residues with a molecular weight of 
72-kDa. It circulates in normal plasma at a concentration of approximately $100 \mu \mathrm{g} / \mathrm{ml}^{26}$. Antibodies directed to human prothrombin (aPT) and the complex of phosphatidylserine/prothrombin (aPS/ PT) are detected by ELISA and have been strongly associated with APS $^{27}$. While the presence of these antibodies have been shown to correlate in some cases ${ }^{28}$, it seems that aPT and aPS/PT belong to different populations of autoantibodies ${ }^{9}$.

A systematic review of the literature including 6000 patients and 1400 controls has been recently reported ${ }^{27}$. aPS/PT was shown to represent a stronger risk factor for thrombosis, both arterial and/or venous, than aPT, with an odds ratio (OR) of $5^{27}$. Data from our group and others suggest that the risk of thrombosis progressively increases with the increase in number of positive aPL tests ${ }^{29-32}$. Recently, we showed that testing positive for all three antibodiesLA, anti-B2GPI and aPS/PT — was the best diagnostic indication of APS $^{33}$. In addition, when compared with double or single positivity, this triple combination showed a stronger correlation with clinical events (thrombosis and/or pregnancy loss).

The mechanisms underlying the procoagulant properties of antibodies to prothrombin are not known; currently two are being postulated: a) indirect; through humoral regulators of coagulation (i.e. prothrombin) or b) direct; engaging/activating cell receptors. An isolated report suggests that polyclonal antibodies from patients with antiprothrombin antibodies might act on a 'target' molecule expressed at the endothelial cell surface ${ }^{34}$, although this is as yet uncharacterised. Tissue factor production induced by aPS/PT in procoagulant cells is reported to occur predominantly via activation of the p38 mitogen-activated protein kinase (MAPK) pathway ${ }^{35}$, similar to the mechanisms implicated in anti- $\beta 2 \mathrm{GPI}$-induced cell activation $^{36}$. In the mouse, active immunisation with prothrombin is associated with increased thrombosis, supporting a role for antibodies to prothrombin in thrombus formation ${ }^{37}$. In addition, mice treated with IS6 (a mouse monoclonal antiprothrombin antibody) show thrombi that are larger and persist longer than in mice injected with control antibody ${ }^{34}$.

\section{Pathogenic mechanisms of aPL}

Despite our incomplete understanding of APS pathogenesis, the major facets have been defined in recent years. Thrombosis, a key feature of the disease, can be the result of various mechanisms, including endothelial cells, monocytes, platelets, coagulation, and complement pathways, as well as blocking of the fibrinolytic and anticoagulation pathways. The conventional understanding is that aPL antibodies bind to receptors on target cells, causing their activation and leading to thrombosis in large vessels ${ }^{38}$. A number of processes have been implicated as effectors of a prothrombotic state in APS. These include: the generation of tissue factor ${ }^{39,40}$; complement activation ${ }^{41-43}$; activated platelet-enhanced endothelial activation $^{44,45}$; monocyte protease receptor activation ${ }^{46}$; and the generation of DNA nets by neutrophils ${ }^{44,45}$.

aPL have been proposed to bind to cellular membranes via various different receptors, including annexin $\mathrm{A} 2^{47-50}$, apolipoprotein E receptor 2 (ApoER2) $)^{51-53}$, low-density-lipoprotein receptor
$(\mathrm{LDL}-\mathrm{R})^{54}$, megalin ${ }^{55}$, Toll-like receptors $2^{56,57}$ and $4^{50,58}$, and the very-LDL-R and P-selectin glycoprotein (GP) ligand-1. It has also been shown that $\beta 2$ GPI is able to directly bind to the platelet adhesive receptor GPIb $\alpha^{59,60}$ and the platelet factor4 $(\mathrm{PF} 4)^{61}$.

Antibody binding to aPL receptors on target cells activates intracellular mediators like nuclear factor kappa $\mathrm{B}(\mathrm{NF}-\mathrm{\kappa B})$ and p38MAPK ${ }^{62}$.

aPL have also been shown to activate the phosphatidylinositol 3-kinase (PI3K)-AKT pathway. Activation of this signaling cascade engages the mammalian target of rapamycin (mTOR), a kinase modulating cellular growth, proliferation and survival ${ }^{63}$. Polyclonal aPL from APS patients induced a marked increase in S6RP and AKT (Ser473) phosphorylation, two of the components of the mTOR pathway, mediating intimal hyperplasia and chronic vasculopathy often seen in APS $^{63}$.

\section{aPL and the Coagulation System}

aPL have been reported to inhibit the anticoagulant properties of activated protein $\mathrm{C}(\mathrm{APC})^{64,65}$, impair fibrinolysis ${ }^{66-69}$, reduce tissue factor pathway inhibitor (TFPI) activity ${ }^{70,71}$ and $\beta 2$ GPI-thrombin interaction $^{72,73}$, and disrupt the annexin A5 anticoagulant shield ${ }^{74-77}$. The binding of aPL to $\beta 2$ GPI diminishes $\beta 2$ GPI complement regulatory function with the consequent impaired clearance of apoptotic cells ${ }^{78}$.

\section{aPL as risk factors for thrombosis: Scoring Systems in APS}

One of the unexplained matters in APS is why some patients develop thrombotic events while others present with morbidity in pregnancy. While a minority of patients may also develop a life-threatening "catastrophic" form of APS with multiple organ involvement and a high death rate, others never develop any aPLrelated manifestation.

In this context, assessing the patient risk of developing an aPLrelated manifestation is crucially important for physicians. Three score systems have been formulated to quantify the risk of thrombosis/obstetric events in APS ${ }^{31,79,80}$.

In 2011, a risk model for APS diagnosis was developed based on patient positivity for aPL along with their titre and the results obtained for LA investigation ${ }^{31}$. Probability estimates for diagnosis of APS were obtained using logistic regression equations and the authors demonstrated that multiple aPL positivity, primarily the triple association of LA, aCL and anti- $\beta 2 \mathrm{GPI}$, increased the risk of APS. LA was shown to be the strongest aPL associated with the diagnosis of APS.

In an attempt to quantify the risk based on the aPL profile, Otomo et $a l .{ }^{79}$ designed the "antiphospholipid score" or aPL-S. The aPL profiles were analyzed using six ELISAs (IgG/IgM aCL, IgG/ IgM anti- $\beta 2 \mathrm{GPI}$, and $\mathrm{IgG} / \mathrm{IgM}$ aPS/PT) and five clotting assays for LA. An algorithm generated this score, with each assay being assigned different points weighted on the relative risk of having a 
clinical manifestation of APS. The prevalence of APS manifestations increased with the increasing aPL-S, suggesting that the aPL-S could serve as a marker of the "probability" of APS and a valuable tool for predicting thrombosis. An independent validation in a separate cohort of 211 consecutive SLE patients confirmed the aPL-S correlation with a history of thrombosis or pregnancy $\operatorname{loss}^{81}$.

Our newly developed alternative score for APS diagnosis (Global APS score or GAPSS) is based on independent thrombosis and pregnancy loss risk factors ${ }^{80}$. This score accounts for established cardiovascular risk factors and the autoimmune antibodies profile in addition to the aPL profile (criteria $\mathrm{aPL}^{1}$ and non-criteria $\mathrm{aPL}^{82}$ ). We developed and validated the score system in a SLE cohort. The analysis included data on clinical manifestations, conventional cardiovascular risk factors, aPL and autoimmune profile (including ANA, ENA and anti-dsDNA, among others). Weighted points proportional to the $\beta$-regression-coefficient values were assigned to each independent risk factor identified by multivariate analysis. Validation was performed in a second cohort of patients showing statistically significant higher values of GAPSS in those with a clinical history of thrombosis and/or pregnancy loss when compared to those without events.

When applied in a prospectively followed-up cohort of SLE patients, an increase in the GAPSS during this follow up was found to be associated with a 12-fold increase in the risk of vascular events. In detail, an increase of more than 3 GAPSS points seemed to have the best risk accuracy for vascular events with a hazard ratio of $48^{83}$.

This score was also applied to a cohort of primary APS, higher values of GAPSS were seen in APS patients who experienced thrombosis when compared to those with previous pregnancy loss alone. In addition, GAPSS was able to discriminate patients who experienced recurrent thrombotic events from those without recurrences ${ }^{84}$.

This score was independently validated by two groups. Zuily et al. ${ }^{85}$ evaluated the validity of the GAPPS to predict thrombosis in a prospective multicentre cohort study. GAPSS values were significantly higher in patients who experienced a thrombotic event when compared to those without with a reported GAPSS above 16 as a significant predictor of thrombosis in this population. Oku et $a l .{ }^{86}$ confirmed that GAPSS can be successfully used to quantify risk in an independent cohort of patients with autoimmune diseases. GAPSS correlated with a history of APS symptoms, particularly with thrombosis, implying it can be used as an appropriate quantitative marker for APS.

\section{Classification vs. diagnostic criteria}

As stated above, in 1999, definitive classification criteria for APS were published in an international consensus statement ${ }^{4}$ and a subsequent revision was made in $2006^{1}$. A patient with APS must meet at least one of two clinical criteria (vascular thrombosis or complications of pregnancy) and at least one of two laboratory criteria including the persistent presence of lupus anticoagulant
(LA), anticardiolipin antibodies (aCL) and/or anti- $\beta 2$ GPI antibodies of IgG or IgM isotype at medium to high titres in patient's plasma.

These classification criteria are aimed at identifying well defined, relatively homogeneous group of patients, all sharing key features of the condition, as they do not reflect the different features of the disease, as diagnostic criteria should ${ }^{87}$. To date, there are no diagnostic criteria available for APS and, therefore, even with a lack of 'essential' or 'key' features, clinicians should be encouraged to consider the diagnosis in the presence of 'minor' features, providing other causes have been ruled out.

\section{aPL carriers}

Overall data from available studies suggest that asymptomatic aPL carriers bear a $0-2.8 \%$ annual risk of developing a thrombotic event $^{88}$. While the presence of aPL is necessary but not sufficient to provoke a thrombotic event, the "second hit" hypothesis suggests that an additional trigger is needed to initiate a vascular event in aPL carriers.

An early study from $1998^{89}$ evaluated the prevalence of thrombosis in aCL positive patients with SLE. The authors reported that $52 \%$ of aCL carriers developed a thrombotic event during the 10 -year follow up, opening the question on the importance of these antibodies as risk factors for thrombosis. From then, few other studies have estimated the incidence of thrombosis in asymptomatic carriers with aPL. A total of 178 asymptomatic aPL carriers without underlying autoimmune diseases underwent a 3-year prospective observational cohort study and no thrombotic events were reported during follow up ${ }^{90}$. The APLASA study, a randomized, double-blind, placebo-controlled trial investigating the efficacy of low-dose aspirin (LDA) as primary prevention of thrombotic events showed a low incidence of thrombosis in aPL carriers, events occurring in all but one of the cases, in the presence of concomitant thrombosis risk factors and/or systemic autoimmune disease at the time of thrombosis ${ }^{91}$. A prospective study identified hypertension and LA as independent risk factors for a first thrombotic event in asymptomatic aPL carriers ${ }^{92}$.

A recent study evaluating the efficacy and safety of LDA vs. LDA plus low-intensity warfarin in the primary thrombosis prevention of aPL-positive patients with SLE and/or obstetric morbidity reported an incidence of 1.8 events/100 person-years in the randomized group ${ }^{93}$. Interestingly, this incidence was increased to 4.9 events/100 person-years in the observational arm with hypertension being the most frequent additional risk factor.

Evidence shows that patients with more than one positive test, and particularly those with all three positive aPL tests (referred to as triple positive), are those with a strong association with clinical events $^{29,30}$. Therefore, aPL carriers should be risk-stratified according to the aPL status, the presence of other cardiovascular risk factors that should be closely monitored and controlled whenever possible, and the concomitance of other systemic autoimmune diseases. 


\section{Conclusions}

Studies are underway to establish the value of testing for new aPL specificities in the identification of APS in patients with thrombosis and/or pregnancy morbidity, particularly in those for whom repeated testing produces negative results with currently available methods. While their clinical importance and mechanisms of action are far from being fully explored, available data suggest that the presence of these other aPL, particularly anti-DI and aPS/PT antibodies, are useful for risk stratification.

Ongoing research focuses on cell receptors and intracellular signaling pathways involved in the cell activation mediated by aPL. The clarification of these mechanisms is crucial to a better understanding of pathogenesis of APS. Although some controversial data still exist in regards to new specificities, most of the available reports support the association between aPS/PT, and to a lesser extent anti-DI, and the clinical manifestations of APS.
Additional studies to conclusively define the relevance and prognosis impact of testing for these antibodies in the daily routine clinical practice are still required.

When assessing risk, the use of GAPSS may provide valuable information regarding thrombosis or pregnancy loss risk, switching from the concept of aPL as simply diagnostic antibodies to aPL as relevant risk factors for clinical events.

\section{Competing interests}

The authors declare that they have no completing interests.

\section{Grant information}

The author(s) declared that no grants were involved in supporting this work.
1. Miyakis S, Lockshin MD, Atsumi T, et al.: International consensus statement on an update of the classification criteria for definite antiphospholipid syndrome (APS). J Thromb Haemost. 2006; 4(2): 295-306.

PubMed Abstract | Publisher Full Text

2. Hughes GR: Hughes' syndrome: the antiphospholipid syndrome. A historical view. Lupus. 1998; 7(Suppl 2): S1-4. PubMed Abstract

3. F Abreu MM, Danowski A, Wahl DG, et al:: The relevance of "non-criteria" clinical manifestations of antiphospholipid syndrome: 14th International Congress on Antiphospholipid Antibodies Technical Task Force Report on Antiphospholipid Syndrome Clinical Features. Autoimmun Rev. 2015; 14(5): 401-14.

PubMed Abstract | Publisher Full Text | F1000 Recommendation

4. Wilson WA, Gharavi AE, Koike T, et al.: International consensus statement on preliminary classification criteria for definite antiphospholipid syndrome: report of an international workshop. Arthritis Rheum. 1999; 42(7): 1309-11. PubMed Abstract | Publisher Full Text

5. Galli M, Luciani D, Bertolini G, et al.: Lupus anticoagulants are stronger risk factors for thrombosis than anticardiolipin antibodies in the antiphospholipid syndrome: a systematic review of the literature. Blood. 2003; 101(5): 1827-32. PubMed Abstract | Publisher Full Text

6. Horbach DA, van Oort E, Donders RC, et al.: Lupus anticoagulant is the strongest risk factor for both venous and arterial thrombosis in patients with systemic lupus erythematosus. Comparison between different assays for the detection of antiphospholipid antibodies. Thromb Haemost. 1996; 76(6): 916-24. PubMed Abstract

7. Wahl DG, Guillemin F, de Maistre E, et al:: Risk for venous thrombosis related to antiphospholipid antibodies in systemic lupus erythematosus--a metaanalysis. Lupus. 1997; 6(5): 467-73. PubMed Abstract | Publisher Full Text

8. Bertolaccini ML, Amengual O, Andreoli L, et al:: 14th International Congress on Antiphospholipid Antibodies Task Force. Report on antiphospholipid syndrome laboratory diagnostics and trends. Autoimmun Rev. 2014; 13(9): 917-30. PubMed Abstract | Publisher Full Text

9. Bertolaccini ML, Gomez S, Pareja JF, et al.: Antiphospholipid antibody tests: spreading the net. Ann Rheum Dis. 2005; 64(11): 1639-43. PubMed Abstract | Publisher Full Text | Free Full Text

10. McNeil HP, Simpson RJ, Chesterman CN, et al:: Anti-phospholipid antibodies are directed against a complex antigen that includes a lipid-binding inhibitor of coagulation: beta 2-glycoprotein I (apolipoprotein H). Proc Natl Acad Sci U S A. 1990; 87(11): 4120-4.

PubMed Abstract | Publisher Full Text | Free Full Text

11. Miyakis S, Giannakopoulos B, Krilis SA: Beta 2 glycoprotein l--function in health and disease. Thromb Res. 2004: 114(5-6): 335-46. PubMed Abstract | Publisher Full Text

12. Iverson GM, Victoria EJ, Marquis DM: Anti-beta2 glycoprotein I (beta2GPI) autoantibodies recognize an epitope on the first domain of beta2GPI.
Proc Natl Acad Sci U S A. 1998; 95(26): 15542-6.

PubMed Abstract | Publisher Full Text | Free Full Text

13. de Laat B, Mertens K de Groot PG: Mechanisms of disease: antiphospholipid antibodies-from clinical association to pathologic mechanism. Nat Clin Pract Rheumatol. 2008; 4(4): 192-9.

PubMed Abstract | Publisher Full Text

14. de Laat B, Derksen RH, Urbanus RT, et al:: IgG antibodies that recognize epitope Gly40-Arg43 in domain I of $\beta_{2}$-glycoprotein I cause LAC, and their presence correlates strongly with thrombosis. Blood. 2005; 105(4): 1540-5. PubMed Abstract | Publisher Full Text

15. F Andreoli L, Chighizola CB, Nalli C, et al:: Clinical characterization of antiphospholipid syndrome by detection of IgG antibodies against $\beta_{2}$ glycoprotein i domain 1 and domain 4/5: ratio of anti-domain 1 to anti-domain $4 / 5$ as a useful new biomarker for antiphospholipid syndrome. Arthritis Rheumatol. 2015; 67(8): 2196-204.

PubMed Abstract | Publisher Full Text F1000 Recommendation

16. de Laat B, Pengo V, Pabinger I, et al:: The association between circulating antibodies against domain I of $\beta_{2}$-glycoprotein I and thrombosis: an international multicenter study. J Thromb Haemost. 2009; 7(11): 1767-73. PubMed Abstract | Publisher Full Text

17. Banzato A, Pozzi N, Frasson R, et al:: Antibodies to Domain I of $\beta_{2}$ Glycoprotein I are in close relation to patients risk categories in Antiphospholipid Syndrome (APS). Thromb Res. 2011; 128(6): 583-6. PubMed Abstract | Publisher Full Text

18. F Akhter E, Shums Z, Norman GL, et al:: Utility of antiphosphatidylserine/ prothrombin and IgA antiphospholipid assays in systemic lupus erythematosus. J Rheumatol. 2013; 40(3): 282-6. PubMed Abstract | Publisher Full Text | Free Full Text | F1000 Recommendation

19. F Pericleous C, Ferreira I, Borghi O, et al:: Measuring IgA Anti-B2-Glycoprotein I and IgG/IgA Anti-Domain I Antibodies Adds Value to Current Serological I and IgG/lgA Anti-Domain I Antibodies Adds Value to Current Serological
Assays for the Antiphospholipid Syndrome. PLoS One. 2016; 11(6): e0156407. PubMed Abstract | Publisher Full Text | Free Full Text | F1000 Recommendation

20. F Wahezi DM, llowite NT, Wu XX, et al:: Annexin A5 anticoagulant activity in children with systemic lupus erythematosus and the association with antibodies to domain I of $\beta 2$-glycoprotein I. Lupus. 2013; 22(7): 702-11. PubMed Abstract | Publisher Full Text | Free Full Text | F1000 Recommendation

21. Andreoli L, Nalli C, Motta M, et al:: Anti- $\beta_{2}$-glycoprotein I IgG antibodies from 1 -year-old healthy children born to mothers with systemic autoimmune diseases preferentially target domain 4/5: might it be the reason for their 'innocent' profile? Ann Rheum Dis. 2011; 70(2): 380-3. PubMed Abstract | Publisher Full Text

22. F Agostinis C, Durigutto P, Sblattero D, et al:: A non-complement-fixing antibody to $\beta 2$ glycoprotein I as a novel therapy for antiphospholipid syndrome. Blood. 2014; 123(22): 3478-87.

PubMed Abstract | Publisher Full Text | F1000 Recommendation

23. Ioannou $\mathrm{Y}$, Romay-Penabad $\mathrm{Z}$, Pericleous $\mathrm{C}$, et al:: In vivo inhibition of 
antiphospholipid antibody-induced pathogenicity utilizing the antigenic targe peptide domain I of $\beta_{2}$-glycoprotein I: proof of concept. J Thromb Haemost. 2009; 7(5): 833-42.

PubMed Abstract | Publisher Full Text

24. F Pericleous C, Ruiz-Limón P, Romay-Penabad Z, et al.: Proof-of-concept study demonstrating the pathogenicity of affinity-purified IgG antibodies directed to domain I of $\beta_{2}$-glycoprotein I in a mouse model of anti-phospholipid directed to domain I of $\beta_{2}$-glycoprotein I in a mouse model of anti-phosphoil
antibody-induced thrombosis. Rheumatology (Oxford). 2015; 54(4): 722-7. PubMed Abstract | Publisher Full Text | Free Full Text | F1000 Recommendation

25. F Zandman-Goddard G, Pierangeli SS, Gertel S, et al:: Tolerogenic dendritic cells specific for $\boldsymbol{\beta}_{2}$-glycoprotein-I Domain-I, attenuate experimental antiphospholipid syndrome. J Autoimmun. 2014; 54: 72-80. PubMed Abstract | Publisher Full Text | F1000 Recommendation

26. Chow BK, Ting V, Tufaro F, et al:: Characterization of a novel liver-specific enhancer in the human prothrombin gene. J Biol Chem. 1991; 266(28): 18927-33. PubMed Abstract

27. Sciascia S, Sanna G, Murru V, et al:: Anti-prothrombin (aPT) and antiphosphatidylserine/prothrombin (aPS/PT) antibodies and the risk of thrombosis in the antiphospholipid syndrome. A systematic review. Thromb Haemost. 2014; 111(2): 354-64. PubMed Abstract | Publisher Full Text

28. Bertolaccini ML, Atsumi T, Koike T, et al: Antiprothrombin antibodies detected in two different assay systems. Prevalence and clinical significance in systemic lupus erythematosus. Thromb Haemost. 2005; 93(2): 289-97. PubMed Abstract | Publisher Full Text

29. Pengo V, Ruffatti A, Legnani C, et al:: Clinical course of high-risk patients diagnosed with antiphospholipid syndrome. J Thromb Haemost. 2010; 8(2): 237-42.

PubMed Abstract | Publisher Full Text

30. Pengo V, Biasiolo A, Pegoraro C, et al.: Antibody profiles for the diagnosis of antiphospholipid syndrome. Thromb Haemost. 2005; 93(6): 1147-52. PubMed Abstract | Publisher Full Text

31. Sciascia S, Cosseddu D, Montaruli B, et al.: Risk Scale for the diagnosis of antiphospholipid syndrome. Ann Rheum Dis. 2011; 70(8): 1517-8. PubMed Abstract | Publisher Full Text

32. Pengo V, Ruffatti A, Legnani C, et al.: Incidence of a first thromboembolic event in asymptomatic carriers of high-risk antiphospholipid antibody profile: a multicenter prospective study. Blood. 2011; 118(17): 4714-8. PubMed Abstract | Publisher Full Text

33. Sciascia S, Murru V, Sanna G, et al:: Clinical accuracy for diagnosis of antiphospholipid syndrome in systemic lupus erythematosus: evaluation of 23 possible combinations of antiphospholipid antibody specificities. J Thromb Haemost. 2012; 10(12): 2512-8.

PubMed Abstract | Publisher Full Text

34. Vega-Ostertag M, Liu X, Kwan-Ki H, et al:: A human monoclonal antiprothrombin antibody is thrombogenic in vivo and upregulates expression of tissue factor and E-selectin on endothelial cells. Br J Haematol. 2006; 135(2): 214-9. PubMed Abstract | Publisher Full Text

35. F Oku K, Amengual O, Zigon $\mathrm{P}$, et al.: Essential role of the p38 mitogenactivated protein kinase pathway in tissue factor gene expression mediated by the phosphatidylserine-dependent antiprothrombin antibody. Rheumatology (Oxford). 2013; 52(10): 1775-84.

PubMed Abstract | Publisher Full Text | F1000 Recommendation

36. López-Pedrera C, Buendía P, Cuadrado MJ, et al:: Antiphospholipid antibodies from patients with the antiphospholipid syndrome induce monocyte tissue factor expression through the simultaneous activation of NF-kappaB/Rel proteins via the $\mathrm{p} 38$ mitogen-activated protein kinase pathway, and of the MEK-1/ERK pathway. Arthritis Rheum. 2006; 54(1): 301-11. PubMed Abstract | Publisher Full Text

37. Haj-Yahia S, Sherer Y, et al:: Anti-prothrombin antibodies cause thrombosis in a novel qualitative ex-vivo animal model. Lupus. 2003; 12(5): 364-9. PubMed Abstract | Publisher Full Text

38. Du VX, Kelchtermans $\mathrm{H}$, de Groot PG, et al:: From antibody to clinical phenotype, the black box of the antiphospholipid syndrome: pathogenic mechanisms of the antiphospholipid syndrome. Thromb Res. 2013; 132(3): 319-26. PubMed Abstract | Publisher Full Text

39. Cuadrado MJ, López-Pedrera C, Khamashta MA, et al.: Thrombosis in primary antiphospholipid syndrome: a pivotal role for monocyte tissue factor expression. Arthritis Rheum. 1997; 40(5): 834-41. PubMed Abstract | Publisher Full Text

40. Amengual O, Atsumi T, Khamashta MA, et al:: The role of the tissue factor pathway in the hypercoagulable state in patients with the antiphospholipid syndrome. Thromb Haemost. 1998; 79(2): 276-81. PubMed Abstract

41. Pierangeli SS, Girardi G, Vega-Ostertag M, et al.: Requirement of activation of complement $\mathrm{C} 3$ and $\mathrm{C} 5$ for antiphospholipid antibody-mediated thrombophilia. Arthritis Rheum. 2005; 52(7): 2120-4. PubMed Abstract | Publisher Full Text

42. Oku K, Atsumi T, Bohgaki M, et al.: Complement activation in patients with primary antiphospholipid syndrome. Ann Rheum Dis. 2009; 68(6): 1030-5. PubMed Abstract | Publisher Full Text

43. Breen KA, Seed P, Parmar K, et al.: Complement activation in patients with isolated antiphospholipid antibodies or primary antiphospholipid syndrome.
Thromb Haemost. 2012; 107(3): 423-9.

PubMed Abstract | Publisher Full Tex

44. F Proulle V, Furie RA, Merrill-Skoloff G, et al.: Platelets are required for enhanced activation of the endothelium and fibrinogen in a mouse thrombosis model of APS. Blood. 2014; 124(4): 611-22.

PubMed Abstract | Publisher Full Text | Free Full Text | F1000 Recommendation

45. F Yalavarthi S, Gould TJ, Rao AN, et al.: Release of neutrophil extracellular traps by neutrophils stimulated with antiphospholipid antibodies: a newly identified mechanism of thrombosis in the antiphospholipid syndrome. Arthritis Rheumatol. 2015; 67(11): 2990-3003.

PubMed Abstract | Publisher Full Text | F1000 Recommendation

46. López-Pedrera C, Aguirre MA, Buendía $\mathrm{P}$, et al.: Differential expression of protease-activated receptors in monocytes from patients with primary antiphospholipid syndrome. Arthritis Rheum. 2010; 62(3): 869-77. PubMed Abstract | Publisher Full Text

47. Ma K, Simantov R, Zhang JC, et al.: High affinity binding of beta 2-glycoprotein I to human endothelial cells is mediated by annexin II. J Biol Chem. 2000; 275(20): 15541-8.

PubMed Abstract | Publisher Full Text

48. Zhang J, McCrae KR: Annexin A2 mediates endothelial cell activation by antiphospholipid/anti-beta2 glycoprotein I antibodies. Blood. 2005; 105(5): 1964-9. PubMed Abstract | Publisher Full Text

49. Romay-Penabad Z, Montiel-Manzano MG, Shilagard T, et al.: Annexin A2 is involved in antiphospholipid antibody-mediated pathogenic effects in vitro and in vivo. Blood. 2009; 114(14): 3074-83. PubMed Abstract | Publisher Full Text

50. Sorice M, Longo A, Capozzi A, et al:: Anti-beta2-glycoprotein I antibodies induce monocyte release of tumor necrosis factor alpha and tissue factor by signal transduction pathways involving lipid rafts. Arthritis Rheum. 2007; 56(8): 2687-97. PubMed Abstract | Publisher Full Text

51. F Ramesh S, Morrell CN, Tarango C, et al:: Antiphospholipid antibodies promote leukocyte-endothelial cell adhesion and thrombosis in mice by antagonizing eNOS via beta2GPI and apoER2. J Clin Invest. 2011; 121(1): 120-31. PubMed Abstract | Publisher Full Text | Free Full Text | F1000 Recommendation

52. Romay-Penabad Z, Aguilar-Valenzuela R, Urbanus RT, et al.: Apolipoprotein $E$ receptor $\mathbf{2}$ is involved in the thrombotic complications in a murine model of the antiphospholipid syndrome. Blood. 2011;117(4): 1408-14. PubMed Abstract | Publisher Full Text | Free Full Text

53. F Ulrich V, Gelber SE, Vukelic M, et al:: ApoE Receptor 2 Mediation of Trophoblast Dysfunction and Pregnancy Complications Induced by Antiphospholipid Antibodies in Mice. Arthritis Rheumatol. 2016; 68(3): 730-9. PubMed Abstract | Publisher Full Text | Free Full Text | F1000 Recommendation

54. Pennings MT, van Lummel M, Derksen RH, et al.: Interaction of beta2-glycoprotein I with members of the low density lipoprotein receptor family. $J$ Thromb Haemost. 2006; 4(8): 1680-90

PubMed Abstract | Publisher Full Text

55. Moestrup SK, Schousboe I, Jacobsen C, et al:: beta2-glycoprotein-I (apolipoprotein H) and beta2-glycoprotein-I-phospholipid complex harbor a recognition site for the endocytic receptor megalin. J Clin Invest. 1998; 102(5): 902-9. PubMed Abstract | Publisher Full Text | Free Full Text

56. Satta N, Kruithof EK, Fickentscher C, et al.: Toll-like receptor 2 mediates the activation of human monocytes and endothelial cells by antiphospholipid antibodies. Blood. 2011; 117(20): 5523-31.

PubMed Abstract | Publisher Full Text

57. Alard J, Gaillard F, Daridon C, et al.: TLR2 is one of the endothelial receptors for beta 2-glycoprotein I. J Immunol. 2010; 185(3): 1550-7. PubMed Abstract | Publisher Full Text

58. Pierangeli SS, Vega-Ostertag ME, Raschi E, et al.: Toll-like receptor and antiphospholipid mediated thrombosis: in vivo studies. Ann Rheum Dis. 2007; 66(10): 1327-33.

PubMed Abstract | Publisher Full Text | Free Full Text

59. Shi T, Giannakopoulos B, Yan X, et al.: Anti-beta2-glycoprotein I antibodies in complex with beta2-glycoprotein I can activate platelets in a dysregulated manner via glycoprotein Ib-IX-V. Arthritis Rheum. 2006; 54(8): 2558-67. PubMed Abstract | Publisher Full Text

60. Urbanus RT, Pennings MT, Derksen RH, et al:: Platelet activation by dimeric beta2-glycoprotein I requires signaling via both glycoprotein Ibalpha and apolipoprotein E receptor 2'. J Thromb Haemost. 2008; 6(8): 1405-12. PubMed Abstract | Publisher Full Text

61. Sikara MP, Routsias JG, Samiotaki M, et al:: \{beta\}2 Glycoprotein I (\{beta\}2GPI) binds platelet factor 4 (PF4): implications for the pathogenesis of antiphospholipid syndrome. Blood. 2010; 115(3): 713-23. PubMed Abstract | Publisher Full Text

62. Poulton K, Rahman A, Giles I: Examining how antiphospholipid antibodies activate intracellular signaling pathways: a systematic review. Semin Arthritis Rheum. 2012; 41(5): 720-36. PubMed Abstract | Publisher Full Text

63. F Canaud G, Bienaimé $F$, Tabarin F, et al:: Inhibition of the mTORC pathway in the antiphospholipid syndrome. N Engl J Med. 2014; 371(4): 303-12. PubMed Abstract | Publisher Full Text | F1000 Recommendation

64. de Laat B, Eckmann CM, van Schagen M, et al:: Correlation between the potency of a beta2-glycoprotein I-dependent lupus anticoagulant and the level of 
resistance to activated protein C. Blood Coagul Fibrinolysis. 2008; 19(8): 757-64 PubMed Abstract | Publisher Full Text

65. Galli M, Willems GM, Rosing J, et al:: Anti-prothrombin IgG from patients with anti-phospholipid antibodies inhibits the inactivation of factor Va by activated protein C. Br J Haematol. 2005; 129(2): 240-7.

PubMed Abstract | Publisher Full Text

66. Patterson AM, Ford I, Graham A, et al: The influence of anti-endothelial/ antiphospholipid antibodies on fibrin formation and lysis on endothelial cells. Br J Haematol. 2006; 133(3): 323-30.

PubMed Abstract | Publisher Full Text

67. leko M, Yoshida M, Naito S, et al:: Increase in plasma thrombin-activatable fibrinolysis inhibitor may not contribute to thrombotic tendency in antiphospholipid syndrome because of inhibitory potential of antiphospholipid antibodies toward TAFI activation. Int $J$ Hematol. 2010; 91(5): 776-83. PubMed Abstract | Publisher Full Text

68. Gombás J, Tanka-Salamon A, Skopál J, et al:: Modulation of fibrinolysis by the combined action of phospholipids and immunoglobulins. Blood Coagul Fibrinolysis. 2008; 19(1): 82-8. PubMed Abstract | Publisher Full Text

69. López-Lira F, Rosales-León L, Martínez VM, et al:: The role of beta2-glycoprotein I (beta2GPI) in the activation of plasminogen. Biochim Biophys Acta. 2006; 1764(4): 815-23.

PubMed Abstract | Publisher Full Text

70. Lean SY, Ellery P, Ivey L, et al.: The effects of tissue factor pathway inhibitor and anti-beta-2-glycoprotein-I IgG on thrombin generation. Haematologica. 2006; 91(10): 1360-6. PubMed Abstract

71. LiestøI S, Sandset PM, Jacobsen EM, et al:: Decreased anticoagulant response to tissue factor pathway inhibitor type 1 in plasmas from patients with lupus anticoagulants. $\mathrm{Br} J \mathrm{Haematol}$ 2007; 136(1): 131-7. PubMed Abstract | Publisher Full Text

72. Rahgozar S, Yang Q, Giannakopoulos B, et al:: Beta ${ }_{2}$-glycoprotein I binds

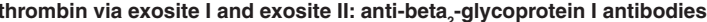
potentiate the inhibitory effect of beta - glycoprotein I on thrombin-mediated factor Xla generation. Arthritis Rheum. 2007: 56(2): 605-13. PubMed Abstract | Publisher Full Text

73. Rahgozar S, Giannakopoulos B, Yan X, et al:: Beta ${ }_{2}$-glycoprotein I protects thrombin from inhibition by heparin cofactor II: potentiation of this effect in the presence of anti-beta - -glycoprotein I autoantibodies. Arthritis Rheum. 2008; 58(4): $1146-55$.

PubMed Abstract | Publisher Full Text

74. de Laat B, Wu XX, van Lummel M, et al:: Correlation between antiphospholipid antibodies that recognize domain I of beta2-glycoprotein I and a reduction in the anticoagulant activity of annexin A5. Blood. 2007; 109(4): 1490-4. PubMed Abstract | Publisher Full Text

75. F Rand JH, Wu XX, Quinn AS, et al:: Hydroxychloroquine protects the annexin A5 anticoagulant shield from disruption by antiphospholipid antibodies: evidence for a novel effect for an old antimalarial drug. Blood. 2010; 115(11) 2292-9.

PubMed Abstract | Publisher Full Text | Free Full Text | F1000 Recommendation

76. Hunt BJ, Wu XX, de Laat B, et al.: Resistance to annexin A5 anticoagulant activity in women with histories for obstetric antiphospholipid syndrome. $A m$ J Obstet Gynecol. 2011; 205(5): 485.e17-23.

PubMed Abstract | Publisher Full Text | Free Full Text

77. F Wu XX, Guller S, Rand JH: Hydroxychloroquine reduces binding of antiphospholipid antibodies to syncytiotrophoblasts and restores annexin A5 expression. Am J Obstet Gynecol. 2011; 205(6): 576.e7-14. PubMed Abstract | Publisher Full Text | Free Full Text | F1000 Recommendation

78. Gropp K, Weber N, Reuter M, et al.: $\boldsymbol{\beta}_{2}$-glycoprotein I, the major target in antiphospholipid syndrome, is a special human complement regulator. Blood 2011; 118(10): 2774-83.

PubMed Abstract | Publisher Full Text

79. Otomo K, Atsumi T, Amengual O, et al:: Efficacy of the antiphospholipid score for the diagnosis of antiphospholipid syndrome and its predictive value for thrombotic events. Arthritis Rheum. 2012; 64(2): 504-12. PubMed Abstract | Publisher Full Text

80. Sciascia S, Sanna G, Murru V, et al.: GAPSS: the Global Anti-Phospholipid Syndrome Score. Rheumatology (Oxford). 2013; 52(8): 1397-403. PubMed Abstract | Publisher Full Text

81. Sciascia S, Bertolaccini ML, Roccatello D, et al.: Independent validation of the antiphospholipid score for the diagnosis of antiphospholipid syndrome. Ann Rheum Dis. 2013; 72(1): 142-3. PubMed Abstract | Publisher Full Text

82. Bertolaccini ML, Amengual O, Atsumi T, et al.: 'Non-criteria' aPL tests: report of a task force and preconference workshop at the 13th International Congress on Antiphospholipid Antibodies, Galveston, TX, USA, April 2010. Lupus. 2011 20(2): 191-205

PubMed Abstract | Publisher Full Text

83. Sciascia S, Cuadrado MJ, Sanna G, et al.: Prospective validation of the Global AntiPhospholpid Syndrome Score (GAPSS). Arthritis Rheum. 2013; 65: S3.

84. Sciascia S, Sanna G, Murru V, et al:: The global anti-phospholipid syndrome score in primary APS. Rheumatology (Oxford). 2015; 54(1): 134-8. PubMed Abstract | Publisher Full Text

85. F Zuily S, de Laat B, Mohamed S, et al:: Validity of the global antiphospholipid syndrome score to predict thrombosis: a prospective multicentre cohort study. Rheumatology (Oxford). 2015; 54(11): 2071-5. PubMed Abstract | Publisher Full Text | F1000 Recommendation

86. Oku K, Amengual O, Bohgaki T, et al:: An independent validation of the Global Anti-Phospholipid Syndrome Score in a Japanese cohort of patients with autoimmune diseases. Lupus. 2015; 24(7): 774-5 PubMed Abstract | Publisher Full Text

87. Aggarwal R, Ringold S, Khanna D, et al.: Distinctions between diagnostic and classification criteria? Arthritis Care Res (Hoboken). 2015; 67(7): 891-7. PubMed Abstract | Publisher Full Text | Free Full Text

88. Barbhaiya M, Erkan D: Primary thrombosis prophylaxis in antiphospholipid antibody-positive patients: where do we stand? Curr Rheumatol Rep. 2011; 13(1): 59-69.

PubMed Abstract | Publisher Full Text

89. Shah NM, Khamashta MA, Atsumi T, et al:: Outcome of patients with anticardiolipin antibodies: a 10 year follow-up of 52 patients. Lupus. 1998; 7(1): 3-6. PubMed Abstract | Publisher Full Text

90. Girón-González JA, García del Río E, Rodríguez C, et al.: Antiphospholipid syndrome and asymptomatic carriers of antiphospholipid antibody: prospective analysis of 404 individuals. J Rheumatol. 2004; 31(8): 1560-7. PubMed Abstract

91. Erkan D, Harrison MJ, Levy R, et al:: Aspirin for primary thrombosis prevention in the antiphospholipid syndrome: a randomized, double-blind, placebocontrolled trial in asymptomatic antiphospholipid antibody-positive individuals. Arthritis Rheum. 2007; 56(7): 2382-91. PubMed Abstract | Publisher Full Text

92. Ruffatti A, Del Ross T, Ciprian M, et al.: Risk factors for a first thrombotic event in antiphospholipid antibody carriers: a prospective multicentre follow-up study. Ann Rheum Dis. 2011; 70(6): 1083-6.

PubMed Abstract | Publisher Full Text

93. Cuadrado MJ, Bertolaccini ML, Seed PT, et al.: Low-dose aspirin vs low-dose aspirin plus low-intensity warfarin in thromboprophylaxis: a prospective, multicentre, randomized, open, controlled trial in patients positive for antiphospholipid antibodies (ALIWAPAS). Rheumatology (Oxford). 2014; 53(2): 275-84. PubMed Abstract | Publisher Full Text 


\section{Open Peer Review}

\section{Current Peer Review Status:}

\section{Editorial Note on the Review Process}

Faculty Reviews are review articles written by the prestigious Members of Faculty Opinions. The articles are commissioned and peer reviewed before publication to ensure that the final, published version is comprehensive and accessible. The reviewers who approved the final version are listed with their names and affiliations.

\section{The reviewers who approved this article are:}

\section{Version 1}

\section{Michael D Lockshin}

Hospital for Special Surgery, Weill Cornell Medical College, New York, NY, USA

Competing Interests: No competing interests were disclosed.

\section{Imad Uthman}

Division of Rheumatology, American University of Beirut, Beirut, Lebanon

Competing Interests: No competing interests were disclosed.

The benefits of publishing with F1000Research:

- Your article is published within days, with no editorial bias

- You can publish traditional articles, null/negative results, case reports, data notes and more

- The peer review process is transparent and collaborative

- Your article is indexed in PubMed after passing peer review

- Dedicated customer support at every stage

For pre-submission enquiries, contact research@f1000.com 